\title{
Non-VEGFR Tyrosine Kinase Inhibitor
}

National Cancer Institute

\section{Source}

National Cancer Institute. Non-VEGFR Tyrosine Kinase Inhibitor. NCI Thesaurus. Code C161820.

Any tyrosine kinase inhibitor that does not target and inhibit vascular endothelial growth factor receptor (VEGFR). 